${ }^{I}$ Federal University of Santa Catarina (UFSC),

Florianópolis, SC, Brazil

carlos.sell@ufsc.br

Carlos Eduardo Sell

\title{
MAX WEBER AND THE DEBATE ON SOCIAL CLASSES IN BRAZIL
}

Reflecting the deep economic and social transformations experienced by Brazil over recent decades, research on social classes has moved to the centre of contemporary political and sociological discussion (Santos, 2004). The rise of a new contingent of individuals to higher socioeconomic levels of income and consumption has been accompanied by an intense academic and political dispute over the effects contained in this change (Neri, 2008; Souza \& Lamounier, 2010). Over and above the description and characterization of the sociological profile of the sectors incorporated into new consumption patterns and lifestyles, what is ultimately at issue in this debate is the very definition of this stratum and its place in Brazil's social structure (Guerra, 2006). Responding to this question about who the middle class is, and what it wants, seems to have transformed into the key to understanding contemporary Brazil. Or to put it otherwise: in today's Brazil, the sociology of classes has been converted into a sociology of the middle class.

In this article, however, I am not concerned with this slippery term 'middle.' My initial premise is that, looking beyond the empirical challenges posed by this task (noting that the studies in this area evince an increasing technical refinement and sophistication), numerous theoretical challenges are also raised. Consequently I do not believe, as Freitas (2010: 75) sustains, that "the 'Marx' of Eric O. Wright and the 'Weber' of John H. Goldthorpe are all the area needs." Taking a polemical stand against the instrumental-em- 
piricist reading of science informing this assertion, ${ }^{\mathrm{I}}$ I contend that the influence of theoretical choices on the research process is, alongside the empirical dimension, a vital element in this discussion. Bearing in mind the long history of this problematics and the ever-expanding international literature on the topic, the heuristic dimension also demands considerable investment.

The present study aims to contribute precisely to the analytic aspects of the debate, albeit from a fairly specific and localized but - I believe - no less decisive angle. Setting out from a dialogue with the sociology of knowledge, my intention is to critically investigate two aspects of the theoretical discussion surrounding the study of inequalities in Brazil: I) the problematic and peculiar way in which Max Weber's theory of social stratification was absorbed; and 2) its secondary role in the debate currently taking place. The article comprises, therefore, an exercise in historical revision with a systematic purpose. The first part provides an exegesis of the theme of social stratification in Max Weber's work. In the second part, I describe and critique some of the trajectories and processes that have shaped the haphazard, peculiar and problematic way in which Weber's theory of classes was received in Brazil. In discussing this topic, I identify a number of interpretative distortions and highlight the need for greater conceptual rigour when dealing with this aspect of his work. Moving beyond this historical aspect, though, the premise guiding this article is that the analytic potential of Weber's theory of classes remains underexploited. Hence in the final part of the text I provide a critical review of some of the contemporary debates in German academia concerning the recent developments and repercussions of this approach. What can we learn from this debate? The final part summarizes the text's principal conclusions.

\section{1}

\section{THE TWO VERSIONS OF THE THEORY OF INEQUALITIES IN WEBER}

There is one detail concerning the Weberian theory of social classes that would seem to make all the difference: more than one written version exists of the text where Weber examines this question. Weber's first essay on this subject was a text entitled "Class, Status, Party." The precise moment when this short text was written remains unknown (some point between IgIo and I9I4) but we do know that it was revised by the author in I920, shortly before his death, under the even briefer title: "Status Groups and Classes." Both texts were kept by Marianne Weber and included posthumously in Economy and Society. ${ }^{2}$ This detail has tended to be overlooked by much of the secondary literature, which generally combines the texts, ignoring the perceptible differences in form and content between them. In order to understand the analytic implications of this fact for an analysis of the question of social inequality, 
we have to situate the two texts within the chronological and theoretical evolution of the project of editing Economy and Society.

The detailed research available today on the publication of Economy and Society (Lepsius, 20I2) shows that the book was not originally conceived as two integrated parts, one theoretical and the other applied, as its first editors, Marianne Weber and Johannes Winckelmann, proposed. In fact it was a bundle of texts produced in two main stages. The first set were written by Weber prior to the First World War and were closely linked to the conception of sociology formulated in his I9I3 essay On some categories of comprehensive sociology. Returning to the work in I920, Weber sought to improve the terms of his theoretical proposal and, without altering its basic foundations, present the ideas in a more accessible form. During this textual revision, he abandoned the formula that community action [Gemeinschaftshandeln] was the object of sociology and proposed instead that social action should provide its basic foundation. A fierce controversy exists among Weberian scholars on the extent and consequences of this terminological change. Although some analysts argue that, given these modifications, we can isolate two sociologies within Weber's work (Lichtblau, 20II), here I follow Schluchter's interpretation (2014) which suggests that we are dealing with a process of lexical refinement and theoretical enhancement, much more than a rupture per se. But whatever the case, these modifications undoubtedly have implications for diverse other aspects of Weber's sociological reflection, beginning with the theme of social stratification.

The first and most visible difference in form observable between these two texts is that the title of the first version reflects precisely the three spheres analysed by Weber: the economic, status groups and the political. In the second version, however, the title already announces that the original tripartite schema has been reduced to two variables: class and status group. The theme of political parties was cut from this section and reinserted by Weber in another area of his work, namely his sociology of domination. This change in the form of presentation also conceals more substantial modifications. Consequently, in the section below, rather than providing a conventional review of Weber's arguments, I shall call attention to these differences and, through them, point out some of the interpretative misconceptions that have been reproduced in the secondary literature.

From the viewpoint of content, the main aspect to emphasize is that a reading of the first essay shows clearly that Weber is still exploring the theme from the perspective of the sociology of social groups and their internal power relations. We can deduce this orientation from the fact that this fragment reflects the work plan conceived by him in I9Io and that, as well as the economy and law, or the economy and culture, also aims to explore the economy and social groups (among them, the family, community associations, 
statuses and classes, and the State). This conception was no different to the one that also appeared in IgI4 in which a new and much more expansive work plan [Einteilung] was set out for Economy and Society, where, once again, the theme of groups was maintained. ${ }^{3}$ In congruence with this analytic framework, the question informing the elaboration of the first text is whether or not classes, status groups and parties constitute specific forms of community. Weber's response to this question is very clear: "In our terminology, 'classes' are not communities" (MWG, I/22-I: 72), they are only types of community action. A different situation applies to status groups, which "[i]n contrast to classes [...] are normally groups. They are, however, often of an amorphous kind" (MWG, I/22-I: 82). These conclusions rest on the fact that class is situated in the sphere of the market (an economic order) while status is located in the social order, both of them being conceived as mutually opposed (since statuses possess irrational consequences from the viewpoint of a market economy).

Only in the second version of the text do the concepts of class and status cease to be conceived as phenomena relating to the distribution of power within communities and are embedded in a full-blown theory of inequalities. In other words, it is here alone that we can identify a Weberian theory of social stratification in the strong sense of the term. Not by chance, Weber planned to insert the fragment on class and status after the sociology of domination and before the study of communities, an arrangement that already demonstrates the exclusivity attributed to the topic in question. As well as a new place in the overall layout of Economy and Society, the approach informing the text also changes, which becomes essentially typological (and no longer historical as before). With the advent of this fresh approach, the content of the manuscript acquires a new format. This theory of inequalities is organized around two fundamental variables, which are themselves structured by two concepts: I) Klassenlage (class situation) and 2) Lebensführung (life conduct). The second version of Weber's text, though much shorter than the first, introduces fundamental clarifications and corrections to each of these spheres. ${ }^{4}$

The core role played by the concept of Klassenslage in Weber's schema of the economic dimension is revealed by the fact that class is defined simply as "any group of people that is found in the same class situation" (WuG: 177). Hence the fundamental importance of defining what is understood by 'class situation.' According to Weber, this can be comprehended as follows:

'Class situation' means the typical probability [chances] of I. procuring goods, 2. gaining a position in life and 3 . finding inner satisfactions, a probability which derives from the relative control over goods and skills and from their income-producing uses within a given economic order (WuG, I980: I77). 
Weber uses these criteria to distinguish between two types of classes in the economic sphere, namely: I) the property class [Besitzklasse] and 2) the commercial (or acquisition) class [Erwerbsklasse]. This formulation clearly differentiates this second version from the older version in which the role of 'property' and 'market' in the determination of class situation were not clearly demarcated. This led some commentators to insist (based on the first version of the text) on the thesis that in Weber's work only the market element (in contrast to property, central to Marxism) determines the individual's economic condition. A rapid comparison with the second text already shows this not to be the case. For Weber, property possession defines the property-owning classes, on one hand, while the commercial class is precisely the one whose situation is explained "by the marketability of goods and services" (WuG, I980: 177). Hence, property and market are not antagonistic or mutually exclusive principles, but two distinct and complementary variables that define distinct situations of I) provisions of goods; 2) external position in life; and 3) personal destiny.

As well as clarifying this point, Weber improves another aspect in this second version. He clearly distinguishes class as an element of the 'economic' order from class at a 'social' level. With this aim in mind, he develops another concept absent from the first version, namely that of social class, presented as follows: "the totality of those class situations within which individual and generational mobility is easy and typical" (WuG: I980: I77). In order to define classes in the social sphere, Weber employs criteria distinct from the narrowly economic, since he refers us to a) intragenerational and b) intergenerational factors. This means that, rather than classifying and describing the position of individuals in terms of shared economic conditions, he highlights the mechanisms and processes that involve the transformation and shaping of these economic differences in specific social layers. Based on these criteria, Weber aims to develop, then, a typology of the structure of contemporary society based on four social classes: I) proprietors; 2) petty bourgeoisie; 3) intellectuals and liberal professionals; and 4) workers as a whole. The analytic character of this typology and, above all, its empirical validity in the face of actual reality, is a topic with a vast bibliography and an issue to which I return later. Indeed, this is a fundamental dimension, but for now I provide merely a summary of the elements used by Weber in formulating his configuration of the modern social order: 


\begin{tabular}{|c|c|c|c|c|c|}
\hline \multicolumn{6}{|c|}{ Max Weber: class categories } \\
\hline \multicolumn{3}{|c|}{ Property Class } & \multicolumn{2}{|c|}{ Commercial Class } & \multirow{2}{*}{\begin{tabular}{|l|} 
Social Class \\
The class of \\
property owners \\
and those \\
privileged by \\
education
\end{tabular}} \\
\hline \multirow[t]{3}{*}{$\begin{array}{l}\text { Positively } \\
\text { privileged }\end{array}$} & Rentiers & $\begin{array}{l}\text { Slaves } \\
\text { Land } \\
\text { Mines } \\
\text { Installations } \\
\text { Ships } \\
\text { Securities }\end{array}$ & Entrepreneurs & $\begin{array}{l}\text { Merchants } \\
\text { Shipowners } \\
\text { Industrial Entre. } \\
\text { Agrarian Entre. } \\
\text { Bankers } \\
\text { Financiers }\end{array}$ & \\
\hline & \multirow[t]{2}{*}{ Creditors } & \multirow[t]{2}{*}{$\begin{array}{l}\text { Livestock } \\
\text { Grain } \\
\text { Money }\end{array}$} & $\begin{array}{l}\text { Liberal } \\
\text { Professionals }\end{array}$ & $\begin{array}{l}\text { Physicians } \\
\text { Artists } \\
\text { Lawyers }\end{array}$ & \\
\hline & & & \multicolumn{2}{|c|}{$\begin{array}{l}\text { Workers with monopolistic quali- } \\
\text { fications and skills }\end{array}$} & \\
\hline $\begin{array}{l}\text { Middle } \\
\text { Classes }\end{array}$ & \multicolumn{2}{|c|}{$\begin{array}{l}\text { Sectors possessing } \\
\text { property or education who } \\
\text { obtain a living from the } \\
\text { same }\end{array}$} & \multicolumn{2}{|c|}{$\begin{array}{l}\text { Farmers } \\
\text { Self-employed artisans } \\
\text { Public or private sector officials } \\
\text { Liberal professionals } \\
\text { Workers with monopolistic quali- } \\
\text { fications and skills }\end{array}$} & $\begin{array}{l}\text { Petty bourgeoisie } \\
\text { Propertyless } \\
\text { intellectuals } \\
\text { Specialists } \\
\text { Propertyless } \\
\text { intellectuals } \\
\text { Specialists }\end{array}$ \\
\hline $\begin{array}{l}\text { Negatively } \\
\text { privileged }\end{array}$ & \multicolumn{2}{|c|}{$\begin{array}{l}\text { Unfree (slaves) } \\
\text { Declassed } \\
\text { Paupers }\end{array}$} & Labourers & $\begin{array}{l}\text { Skilled } \\
\text { Semi-skilled } \\
\text { Unskilled }\end{array}$ & $\begin{array}{l}\text { Labourers as a } \\
\text { whole (drilled } \\
\text { work) }\end{array}$ \\
\hline
\end{tabular}

Based on Vester (200I) 
In the text written prior to the First World War, Weber devotes most of his observations to a direct dialogue with the Marxist thesis of the formation of class as a political actor - i.e. the transition from the Klasse an sich [in itself] to the Klasse für sich [for itself]. Or in Weberian terms, to the problem of interests and class action. In his second version, this issue is diluted over the course of the text, although the arguments developed are essentially the same. Basically Weber calls into question the automatic nature of the transition from the economic to the political. In other words, he problematizes the inadequacy of Marx's theorization of the relationship between the economic/ objective dimension and the political/subjective dimension of the classes. From this perspective, the formation of classes as political groups (class action) is not an intrinsic necessity but a contingent political construction involving diverse factors. ${ }^{6}$ Pursuing the same logic, the identity of interests does not automatically lead to the class struggle (or action) and the latter, in turn, does not necessarily lead to revolution. At any rate, in the second version of his work the political factor ceases to be an independent analytic element of the Weberian theory of social stratification. The idea that power, alongside the economic and the social, constitutes a third element of his theory of social hierarchies is, in fact, an a posteriori reconstruction that takes as its starting point the text from the earlier part of Economy and Society. The final version of the Weberian proposal is dual, not triadic, and based solely on the dimensions of class and status. Consequently, I turn now to this second element.

As already formulated in relation to classes, Weber also distinguishes between 'status group' [Stand]' and 'status situation.' Unlike class situation, where the determining factor is the individual's living conditions [Lebensbedingungen], his or her status situation refers to "an effective claim to social esteem in terms of positive or negative privileges" (WuG: I980: 179) based on the following factors: I) a specific type of life conduct; 2) a formal mode of education (which in turn may be empirical or rational in kind, with its corresponding form of life); ${ }^{8}$ and 3 ) founded on the prestige derived from descent or profession. Finally, Weber also locates the forms through which a person's status situation is manifested. In other words, he identifies the social mechanisms of distinction through which a status group delimits its boundaries. These mechanisms comprise: I) conditions of marriage; 2) commensality; 3) the monopolistic appropriation of acquisition opportunities; ${ }^{9}$ and 4 ) traditions or conventions. It is through these social practices that social limits and boundaries become manifest.

Based on these observations, Weber defines the status group as "a plurality of persons who, within a larger group, successfully claim a) a special social esteem, and possibly also b) status monopolies" (WuG: I980: I79). Turning to analyse status groups, he begins by determining the mechanisms 
responsible for generating the status group situation, distinguishing between three types of processes. The first is primarily historical in nature and involves status by birth. In addition there is a primarily economic type (status by profession) and a political-hierocratic type (political or hierocratic statuses). Hence through these three processes Weber identifies the main social types of modern status groups with their corresponding forms of life: status by birth, by profession and by politics (or religion).

Viewed in retrospect, a comparison between the first theoretical model sketched by Weber (triadic in nature) with this second model (dual) shows that in the latter version class and status group are categories organized through symmetrical heuristic parameters. This advance derives from the fact that Weber organizes his analysis of classes and status groups through the use of aggregation criteria that are simultaneously analytic-descriptive (class situation and status group situation: i.e. an aggregate of positions) and synthetic-explicative, that is, implying the institutionalization of these aggregates in social layers as particular collective units (the social class and status group properly speaking). It is also important to stress that class and status group cannot be dualized as though the former represents an objective factor and the latter a merely subjective factor. Neither can they be formulated as an opposition between the material and the symbolic, since these analytic criteria are present as constitutive dimensions of both poles of the model. For this reason both spheres also constitute principles independent of social stratification. This does not mean that the type of social aggregates that result from them possess the same nature. In the case of (economic or social) classes, the principles of delimitation are open (life chances and personal or generational mobility), while in the case of status groups (based on birth or profession) mechanisms of inclusion/exclusion operate that establish objective social boundaries.

Having made these conceptual distinctions (pure types), two points remain to be debated: namely, the historic and analytic relations between these two domains of hierarchization and social segmentations. From the historical point of view, Weber recognizes that when the status group is the dominant principle of the social order, we encounter a status society (conventional in nature and thus strongly irrational from an economic point of view). But when class is the dominant principle, the result is a classist society. Seen in these terms, modern societies, oriented by a market economy, are generally structured in classes, in contrast to the status-group principle that prevails in the feudal and patrimonial regimes for meeting economic necessities. However it is important we do not lose sight of the fact that the class/ status group distinction is not only historical, but primordially analytical, which implies that status groups should not be taken to be a residual, premodern element. Both class and status group are structuring principles of 
the hierarchical configuration of contemporary societies and each possesses autonomous agency and social effects.

Over and above the historical relation, therefore, we need to prioritize the analytic connection between these two mechanisms of social distinction. Here Weber takes pains to emphasize that neither of these two principles has an analytic priority or an explanatory dominance: neither is class determined by the status situation, nor do status groups depend on the class situation. Nevertheless, treating both principles in autonomous form does not imply either that they comprise two self-contained mechanisms. Just as the status situation can condition the class situation, so certain social sectors can have very different economic living conditions (officer, civil servant, student) even though their social prestige may be the same. Weber turns to history to recall that "[s]tatus groups are often created by property classes," without also forgetting that class formations can develop status group characteristics: "The status group comes closest to the social class and is meet unlike the commercial class" (WuG: I980: 180). Hence multiple causal relations are involved in which both status group and class assume the role of dependent or independent variable.

More than just elements of a social structure, class and status group perform a strategic role in Weber's sociological inquiries, focused primarily on understanding modern entrepreneurial capitalism and the specificity of western rationalism. These two dimensions are also articulated by the concept of 'profession' [Beruf], which, as we know, constitutes for Weber the social type par excellence of the modern individual. The importance and influence of the Weberian model in studies of class in the social sciences requires no further comments. To evaluate this impact I begin by highlighting a number of aspects of the singular way in which it was received in Brazil.

\section{2}

\section{THE PECULIAR BRAZILIAN RECEPTION: TWO MOMENTS}

The project of describing and elucidating the historical and social peculiarities of the trajectories through which Weber's thought was absorbed in Brazil and how it shaped a particular reading of the country has gained impetus over recent years. We can identify two basic lines of inquiry: the historical and the sociological. The first line focuses on a comparative analysis of the reception of Weber's texts (Mata, 2013), while the second foregrounds the study of contexts that shape the mechanisms involved in the selection and appropriation of his ideas (Villas Bôas, 20I4). On this topic I situate myself in this second line of research and, without any pretence of filling all the historical gaps involved in this process, I concentrate on describing two distinct moments (Jackson \& Blanco, 20I4) in the absorption of Weber's sociology of social stratification: I) the moment when the social sciences formed 
and expanded academically; and 2) the contemporary moment, characterized by its thematic specialization. Rather than a strictly historiographic reconstruction, my aim is primarily theoretical in kind and looks to highlight some of the impacts and implications of Weber's work within the sociological field.

In the first phase of this reception, the birth of a body of literature dedicated to the systematic study of Weber's ideas is closely connected to the role of what became known as the São Paulo School of Sociology (Escola Sociológica Paulista) and its project of constructing a scientific sociology. Taking just the translations of Weber's works as an indicator, we would be led to conclude that the author's incorporation in the Brazilian context was a relatively late process, since the first translation of one of his texts into Portuguese was undertaken only in 1967. ${ }^{\text {I0 }}$ However, we should not forget that some of Weber's main theses were already decisively present in Brazilian political and social debates through invaluable pioneering works like Raízes do Brasil (1936) and Os donos do poder (I975) to cite just two of the most important. ${ }^{\text {II }}$ At the same time, little emphasis has been given to the detail that these works - subsequently incorporated into the sociological canon - were not gestated in Sociology Departments and that the formal approach is much more deeply inscribed in the area of social or political history than in sociology as a discipline.

In light of this fact, I argue that the role of the São Paulo School of Sociology is localized in a second moment of Weber's reception in Brazil, during the institutionalization of the compartmentalized social sciences (sociology, anthropology, history, etc.) when a self-reflexive awareness of the epistemological and methodological status of the human sciences was required. This means that Weber's reception in this school already reflects the desire to found and legitimize an area of knowledge inscribed in the sphere of scientific activity, practiced by specialists in the social space of the university. This helps explain why Max Weber, an author who made enormous efforts to investigate the methodological foundations of sociology and formulate a unique conception of the discipline, was mobilized in the discussion of a science then passing through its consolidation phase. This provides a key to understanding two decisive works from this period, namely Fundamentos empíricos da explicação sociológica (Fernandes, 1958) and Crítica e resignação (Cohn, I979), texts which, despite their different emphases, respond to the same intellectual context. This latter acted as a hermeneutic filter through which Weber's theory was read under the sign of synchronicity by Fernandes (in his version, Weber's ideal types represent an anti-historical approach) and of action and power by Cohn (Weber as a resigned critic of modernity). This Weberian Marxism avant la lettre (and despite Merleau-Ponty or the Frankfurt School), with its peculiar hermeneutic critique, pursued its own path in Brazil, functioning as one of the main angles for interpreting Weber's work in this intellectual context. 
One area where this filter is more clearly reflected is precisely the theme of social classes, since it was within the São Paulo School of Sociology that a fairly peculiar form of systemizing this theme in Weber emerged - i.e. the apprehension of his theory via an organizing principle completely different to his texts. This change is far from marginal since instead of $\mathrm{I}$ ) class; 2) status group; and/or 3) party - as found in the first version developed by Weber - we have a new sequence: I) caste; 2) status group; and 3) social class. Two works from this period clearly reveal this undeniable equivocation. The first is the collection of articles edited by Octavio Ianni, Teorias da estratificação social (I97I), which presents precisely the triadic grid above. ${ }^{\mathrm{I} 2}$ Much more influential, however, given its longevity, is the text by Sedi Hirano, based on his doctoral thesis and published in 1974 under the title Castas, estamentos $e$ classes sociais (Hirano, 2002). The result of a systematic comparison between Marx and Weber, Hirano takes up Fernandes's thesis concerning the historical nature of Marx's approach and the poly-historical nature of Weber's, and through this argument, reconstructs the argument of both authors within a diachronic perspective. Applying a historical schema that distinguishes between pre-capitalism and capitalism, the Weberian view is disassembled and reinserted in a sequence in which caste and status group are presented as pre-modern schemas of differentiation, while class is defined as the dominant modern mechanism of social stratification.

The idiosyncratic grid through which Ianni and Hirano present the Weberian theory of stratification is partly explained as an outcome of the particular understanding of sociology that informs the São Paulo School. It also, though, answers the demand for a scientific and universal sociology in opposition to a sociology oriented by contextual imperatives (of the kind advocated by Guerreiro Ramos). For this reason, the insertion of Weber in the 'caste, status group, social class' schema reflects, among other factors, the attempt to construct and fix a theoretical-systematic comprehension of social stratification, precisely as recommended by the approaches dominant in the international literature during the period in question. Hence Marxism, more than an element of a well-seasoned eclecticism, acted as the principal axiological and epistemological axis, relegating Max Weber to the study of the status dimension of Brazilian social life, leaving Marx to shed light on the mechanisms responsible for generating class in a bourgeois social order situated on the periphery of capitalism. Examples include the famous essay by Florestan Fernandes (A revolução burguesa no Brasil) or even the studies by Fernando Henrique Cardoso on the capitalist mode of production in southern Brazil (Capitalismo e escravidão no Brasil meridional). ${ }^{\text {13 }}$

Even so, the triad 'caste/status/class' was not the only factor conditioning how Weber's work on the topic was received in Brazil. It coexisted alongside the triad 'class/status/party,' as divulged from early on through the world 
famous set of articles edited by Wright and Mills (From Max Weber, published in I946), translated in Brazil precisely during this same period (I967). In this way, a peculiar and problematic comprehension of the theme of social stratification in Weber became established in Brazil, sometimes following the modified schema advanced by the São Paulo School of Sociology, sometimes guided by the translation of Wright and Mills's edited volume. In both cases, though, the theoretical evolution observable in Weber's texts, as well the epistemological differences between the two versions, are completely ignored, leading to a fragmented and confused understanding of this theme in Weber.

Given the limits of the present article, I shall be unable to explore in detail the paths through which these competing and contradictory (but interrelated) readings are reproduced, each in its own way, in the secondary literature, neither will I be able to point to their multiple impacts in the area of applied research. Setting this task aside for future investigations, I shall make a leap through history to concentrate on the present moment, looking to situate the place assigned to Weber in the theoretical orientations shaping discussion of the theme of social inequality in contemporary Brazil. Today the terms of this debate have been substantially modified and we can observe that the Weberian legacy is present in a differentiated form in the two main theoretical-methodological currents now vying to interpret the effervescent social dynamics of Brazil during the era of globalization.

The first of these orientations is fundamentally quantitative in kind, focusing on the structural dimension of social hierarchies. In this line of interpretation, the decisive figure in terms of Weber is the British social scientist John Goldthorpe (1963, I992, 1996, 2000). Accompanying the international scenario, Goldthorpe's typology (I992) has had an enormous influence in Brazilian social research, not only because it provides tools for measuring social stratification, but also because it allows international comparisons (Scalon \& Santos, 20I0). Just like Erik Olin Wright in Marxism, Goldthorpe is traditionally cited as the main reference point in the continuity of a Weberian approach to the social classes. However, this stock assumption deserves a more detailed analysis and needs to be taken with due caution. What is really Weberian about Goldthorpe's model? Or, paraphrasing Wright on Marxism, what is exactly 'neo' and what is 'Weberian' in this theory?

From a historical-genealogical perspective, the researcher himself advocates a degree of circumspection in responding to this question, since, he argues, it is somewhat strange to speak of a Weberian tradition of social stratification given Weber's sparse and succinct contributions to the topic. Indeed Goldthorpe defines his connection to the Weberian approach more broadly and indirectly, since, generally speaking, when discussing the subject, Weber ends up serving as a generic label that, despite contradictory interests, comprises a means of qualifying an entire set of alternative or even contrary approaches 
to Marxism. ${ }^{14}$ Conceived in these terms, a Weberian approach remains merely negative and substanceless. Although he aligns himself with the latter position (Goldthorpe, 2007: I26), the term 'Weberian' is attributed a fairly broad sense, including a range of very different actors that, as well as Weber, also includes Schumpeter, Giger, Halbwachs, Marshall, Renner, Corner, Lockwood and (Ralf) Dahrendorf. Furthermore, Goldthorpe's model of seven social classes ${ }^{15}$ is not taken directly from Weber's text but from David Lockwood's theoretical proposal (1958, later reformulated). Consequently between the initial and final product there exists a complex process of mediation and translation of concepts. In sum, in historical terms, the Weberian character of Goldthorpe's theory is much more 'negative' (in opposition to Marxism) than positive, much 'broader' than specific and much more 'indirect' than direct.

If the historical connection is weak, it remains, then, for us to examine the systematic link between Weber's original model and the model proposed by the British sociologist. Are they based on the same principles? On one hand, it is worth recognizing that Goldthorpe (2OI2) remains faithful to one of the basic premises of Weber's study: he assumes that 'class' and 'status' are independent mechanisms of social stratification. In relation to the class dimension, Goldthorpe's model combines market situation and labour situation criteria and takes contractual employment relations as its main indicator, the reason why his model can be seen as much more eclectic than strictly Weberian. However, we have already observed that the 'market situation' criterion tends to be taken, incorrectly, as the principal attribute of Weber's model of class. Furthermore, maintaining and incorporating just one of the (supposed) criteria of the Weberian approach into his theoretical framework is not sufficient for Goldthorpe's theory to be considered a revival and continuation of Weber's. Likewise, the fact that it takes elements from Marxism and Weber does not make the author's theory a 'synthesis' of both. These observations lead to the hypothesis that it would be more accurate to interpret Goldthorpe's theory as an original or self-sufficient proposal that must be defined in its own terms and not through its exclusive or combined affiliation with prior traditions of social thought. I believe, then, that neither neo-Weberian, nor Weberian-Marxian, we are dealing simply with a 'Goldthorpian' theory.

The second of the main approaches to the theme of social inequality in Brazil is qualitative in kind. Its point of reference is the French sociologist Pierre Bourdieu and his well-known and widely deployed typology of capitals. A systematic comparison between the French author's relational sociology of 'practices' and the sociology of 'action' developed by Max Weber still remains to be explored in Brazil. Nonetheless the author tends to be presented as the thinker who advanced on the differentiation introduced by Weber between the strictly economic dimension of the classes in their Marxist version (monist perspective) and their social, cultural and symbolic aspects. From 
this perspective, the work of the author of La distinction (2008) would be the most important development of the multidimensional approach of which Max Weber, for his part, would be the founder.

Not everything is a continuation, though. Bourdieu himself takes as a starting point for his model of social stratification a critique of what he identifies as a fissure between the elements of class and status in Max Weber, who, according to him, "opposes class and status group as two types of real units" (Bourdieu, 20II: I4). This observation is an indication that Bourdieu interpreted Weber through the opposition between the material (class) and the symbolic (status) (see Weininger, 2014). Along with this moving beyond this dichotomy, he also wants to overcome the opposition between the objective (realist) dimension and the subjective (nominalist) dimension of classes (Bourdieu, 1987). From the objective viewpoint, classes are defined in a relational form, not a substantialist form - that is, as objective relations that depend on the distribution of the volume and composition of economic, social and cultural capital (dominant classes, petit bourgeoisie and dominated class). Based on these criteria, he distinguishes between different class segments and strata, with their corresponding habits and lifestyles. This objective dimension is merely classificatory, however, since classes exist as social groups in the subjective dimension as the result of symbolic disputes that, setting out from the objective condition, establish social boundaries. An analysis of the different types of cultural habitus of the social classes is undertaken in La distinction, leading Bourdieu to identify different lifestyles and cultural strategies. To this extent it is the symbolic, rather than the structural, that comprises the key dimension of Bourdieu's theory of classes.

In Brazil, Bourdieu's work has primarily influenced qualitative-type studies. Rather than provide a panorama of this literature, an impossible task in the space available here, I shall explore one of its most exemplary bodies of work, namely the studies of Jessé Souza. At a general level, the author's research is closely connected to the examination of modernity in Brazil. Setting out from Max Weber and a critical reading of Gilberto Freyre, he initially sets out to profile the singularity and selectivity of modern Brazilian institutions (Souza, 2000). However, as his work begins to specialize on the issue of economic-racial selectivity, so his frame of reference shifts: Weber and Gilberto Freyre fade into the background as Pierre Bourdieu and Florestan Fernandes come to provide the new baseline for his exploration. Along this trajectory, his theory of the singularity of modernity in Brazil transmutes into a theory of peripheral modernity (Souza, 2003).

This global theoretical reflection results in an interpretation of the social dynamics of contemporary Brazil where the supposed economicist bias of the liberal and Marxist approaches is thrown into question (Souza, 2013). Seeking to overcome this impasse, the author thus turns to reflect on 
the sociocultural genesis of the classes, explaining why Bourdieu's approach becomes the core theoretical reference. Pursuing this new angle, the objective of his research shifts to verifying directly the existence of an effective process of incorporating new social sectors into the traditional middle class. The explanatory hypothesis ventured by Souza is that the incorporation of new social contingents in the sphere of commodity production and consumption is not accompanied ipso facto by the egalitarian distribution of cultural capital. In other words, it is the symbolic factor that comes to be held responsible for reproducing inequality in the new Brazilian social configuration. At an empirical level, this premise leads to qualitative studies that aim to describe and characterize the lifestyles of these social sectors, oscillating between their categorization as 'structural riffraff' (Souza, 2009), 'fighters' or a 'new working class' (Souza, 20I2), revealing in the process that his empirical hypothesis has yet to encounter adequate conceptual expression.

It is not the aim of this text, however, to test the empirical applicability of quantitative or qualitative studies of classes in Brazil. My objective consists solely of problematizing their analytic premises vis-à-vis the Weberian legacy through two criteria: the historical and the systematic. Let us summarize what has been said so far, therefore. From a historical perspective, both research traditions assign Weber a distinct position and influence in their narratives. In the Goldthorpe line - and despite the innovations and corrections that it introduces - the prefix 'neo' suggests a line of continuity and Weber is vindicated, albeit somewhat generically, as a term of reference. The Bourdieu line, on the contrary, effects a breach since it situates itself as a solution to (or transcendence of) the contradictions inherent to the Weberian legacy. From a systematic perspective, both lines could be said to take (distinct) elements of the Weberian model as their starting point. While the structural research program foregrounded the socioeconomic aspect of Weber's theory of inequality [Klassenlage], pushing its symbolic-expressive dimension [Lebensführung] into the background, in the sociocultural research program it is the structural aspect that is decentred. Borrowing a formulation popular in social theory, we could argue that each of them practices different forms of conflation (Archer, 2005). In the structural program, the symbolic occupies a merely reflexive role, while in the Bourdieusian program it becomes the determinant factor. From this viewpoint, I would argue that neither the structural nor the cultural approach represent or translate the multidimensionality of the Weberian vision of social stratification. Ultimately both reproduce and radicalize the gulf between the 'structural' and the 'symbolic' that has shaped readings of Weber's theory of classes.

Despite the different degrees of influence, in both the lines of research examined here Weber's legacy is reduced to a historical condition (precursor) and each presents itself as an actualization of its potential. It is as though 
everything that Weber had to tell us were contained in some form in these two lines of investigation, whether in relation to the objective or the subjective. Unlike the Marxian/Marxist perspective in which a continuous and systematic endeavour of theoretical renewal of the theme of classes is taken as unproblematic, in Brazil the Weberian perspective quickly resigned itself to the limbo of the history of ideas: while during the institutionalization of sociology in Brazil, Weber was an active presence in the study of the statusbased character of national society, the contemporary period seems to be strongly post-Weberian, or at most semi-Weberian. ${ }^{16}$ Ultimately, therefore, these contemporary developments fail to exhaust the analytic potential of the Weberian schema, which, in my view, remains underexploited. For this reason, I believe that a return to the guiding premises of the Weberian approach to stratification and the social classes can deepen the theoretical debate and, a fortiori, empirical research.

\section{3}

\section{THE RETURN TO WEBER: AN OVERVIEW}

Neither is Weber's legacy limited to the appropriations made by Goldthorpe and Bourdieu of his work, nor do these comprise its most significant and consistent developments. In order to corroborate this reading and extract lessons from it to think about what the Weberian approach still has to offer on the subject, this final section discusses some authors involved in the debate taking place today in Germany. My proposal is not to produce a map or panorama of this debate (a state of the art) but to present a number of analytic possibilities that - directly or indirectly inspired by Weber - feed into the discussion on inequality, hierarchy, stratification and social classes.

One of the most influential currents in the contemporary German debate centres on the category of 'lifestyles' [Lebensstilforschung] (Rössel, 20II). Developing in the I980s (Berger \& Hradil, I990), this theory draws from the writings of Simmel, Weber, Veblen and, today, Beck and Bourdieu, with the aim of "characterizing the principles, objectives and routines through which individuals orient their own lives" (Hradil, 2001: 273). The intention is to describe patterns of representation and action among individuals in the context of a supposedly post-materialist society less and less structured in social groups (the thesis of individualization). Hence its authors propose advancing beyond both the theory of classes and the theory of social strata. Konietzka (I994) identifies two main lines of analysis in this approach (structural and cultural), though most of its critics argue that it ends up pushing the dimension of social structure into the background. The principal contribution of this approach is its attempt to develop typologies that capture different lifestyles (hedonist-expressive, family-centred, cultural-aesthetic, conservativepassive, expressing prestige, conventional-discrete, self-expressive-avant- 
garde). Despite the value of the microsocial dimension to which it alludes, this perspective ultimately confuses the Weberian approach to forms of 'life conduct' [Lebensführung] with the aestheticizing approach of 'lifestyles' [Lebensstil] of Simmelian sociology, leading eventually to a subjective-expressivist vision of social conducts (Müller, 1993, 2002, 2003).

The theory of lifestyles is merely an indirect development of Weberian sociology but is far from being the only one. Reflecting on the theme of classes, Müller (2008: 187) offers us an interesting synthesis of its multiple developments, which he classifies as follows: I) The Marx-Weber symbiosis: class consciousness and life conduct (Giddens); 2) Life chances and social exclusion (Dahrendorf and Parkin); 3) Class and lifestyles (Bourdieu); 4) Economic conditions, formation of political interests and cultural-value orientations (M. Rainer Lepsius). There is no space here to explore each of these currents, each of which, in its own way, conserves something of the Weberian legacy. Given the scope of this work, I shall focus attention on Lepsius's proposal, since this author stands out among this group by his aim of assuming Weber's postulates in full. According to Müller, rather than a sociopolitical theory (Giddens), a sociostructural theory (Dahrendorf and Parkin) or a sociocultural theory (Bourdieu), Lepsius removes each of these questions from its mutual isolation and treats them as a specific dimension of the social dynamics of the social classes.

Seeking to overcome the unilaterality of each of the aforementioned aspects, Lepsius develops an original systemization of Max Weber's thought along three axes: ideas, interests and institutions. The baseline for this reading is a famous passage in which Weber declares that frequently "'world images' that have been created by 'ideas' have, like switchmen, determined the tracks along which action has been pushed by the dynamic of interests" (MWG I/I9: IOI). Into this schema Lepsius introduces a third variable - institutions - allowing us to consider the different relations between each of the three dimensions (Schluchter, 2014: 56). Taking this understanding of Weberian sociology as a framework, Lepsius presents his theory of social stratification as follows:

The question of the meaning of class structure [...] should be explored at the level of the description of life conditions [Lebenslage], at the level of the investigation of the processes of interest formation and their institutional representation, and at the level of value orientations [Wertorientierungen] and in their significance for the processes of constitutional legitimization of and compliance with the processes of interest intermediation (Lepsius, 2009: II8).

At the structural level, Lepsius produces an analysis of class structure that adopts a schema exactly like the classification (taxonomy) proposed by Weber. Rather than dwelling on the conjunctural conclusions of his data, I wish to call attention to his methodological operationalization of the Webe- 
rian model, since it is here, I believe, that the originality and actuality of the author's proposal reside. For Lepsius the so-called 'property classes' (economically autonomous) are in quantitative decline, though this does not imply that we should underestimate their qualitative significance, especially their capacity for savings and investment. Today the structural pattern of modern societies is primarily determined by the 'commercial classes,' the sector in which he also observes a heightened process of internal differentiation marked by the growing fissure between the traditional working class and underprivileged groups. One novelty in Lepsius's schema is the introduction of a new classificatory variable into the Weberian class model: the Versorgungsklasse or 'welfare class,' composed especially of women and immigrants. He defines the latter as "a class whose forms of procuring goods, position in life and inner life are determined by various modes of wage transfer based on social policies and access to public goods and services" (Lepsius, 2009: I28).

Faithful to Weber's schema, Lepsius thus shifts from classes as economic aggregates to classes as social collectives. The conclusion to his analysis is the declining number of individuals situated in the 'proprietor' and 'petty bourgeois' sectors. On the other hand, there is a strong growth of 'intellectuals' and 'liberal professionals,' while 'labourers' are undergoing an acute process of differentiation caused, among other factors, by a labour market formed increasingly by immigrants. What this rapid examination shows, therefore, is that while directly adopting Weber's analytic schema, Lepsius enriches and modifies this model in response to the historical transformations presently under way.

At the political level, just as in Weber's work, Lepsius does not take power to be an independent factor of social stratification, though equally this does not imply that the political dimension has no place in his analysis. Understanding social hierarchies under the aegis of political sociology means assessing the impact of the social structure described above on the correlation of forces between different social groups. His observations lead him to conclude that a process of institutionalization of social conflicts (the Welfare State) is accompanied by a multiplication of the arenas of power (the State, market and associativism). In this scenario the lines of conflict become separated and specified, diluting the centrality of class confrontation: social conflict ceases to be systematic and becomes a dispute over the allocation of resources, neutralizing movements of class mobilization that advocate political ruptures.

It is principally at the cultural level that Lepsius is particularly innovative since rather than resorting exclusively to the Weberian notion of status group, he replaces it with an investigation of the cultural dimension of social classes. In this way he combines the Weber-inspired notion of value orienta- 
tions [Wertorientierungen] with the concept of subculture, or more precisely class culture. Although the reference to the idea of value orientations seems to me a valid and necessary step, insofar as it connects with the Weberian question of meaning, I believe that its translation via the concept of 'subculture' is somewhat outmoded. Nonetheless, it also carries with it another vital concept in the author's theoretical framework, one that has acquired a huge centrality in the current academic debate: this is the concept of sociomoral milieu [sozialmoralisches Milieu] (Lepsius, I993: 38) employed by the author as a means to identify types of party orientation in the German social cartography (liberal-Protestant, Protestant-conservative, Catholic and socialdemocrat).

In his later use, as it happens, the notion of social milieu acquired new connotations and developed in different directions. Nowak and Becker (I985: I4), for example, define the social milieu as "groups of individuals with similar views and forms of life and who for this reason form subcultural units within society." Even supporters of critical views of class like Vester (200I) have sought to incorporate the concept as an instrument supposedly suitable to capturing the horizontal dimension of new forms of inequality and social structuring (Kreckel, I992). New typologies emerged in the wake of this movement, seeking to depict the different spaces of socialization and their corresponding patterns of values and modes of action. One of the most important is the SINUS Institute, ${ }^{17}$ which distinguishes the following types of social environments: conservative, liberal-technocratic, petit bourgeoisie, upwardly mobile middle class, new workers, traditional working class, traditionless working class, hedonistic and alternative. This concern with the elaboration of descriptive typologies has led the social milieu approach into a somewhat confused symbiosis with research on lifestyles, even though the former differs due to the centrality afforded in its analysis to the formation of social groups via the process of socialization. Consequently, this approach does not eclipse the structural dimension per se, though it seeks to define it from the viewpoint of the cultural rather than through economic conditions.

The richness of Lepsius's multidimensional reflection does not reside at the abstract level alone: it can be particularly appreciated at the empirical level too, as in the case of his important sociology of the bourgeoisie and the bourgeois nature (Lepsius, 2009: I53-169), a point where he revives the triad of interests, ideas and institutions. Taken in its merely sociostructural sense (based on the criteria of property and education), the bourgeoisie is a generic concept that encompasses heterogeneous social groups. To go beyond this descriptive and amorphous sense and comprehend the bourgeoisie as a both privileged economic layer and a homogenous social group, we also need to consider its political and cultural aspects. This involves considering the dynamic social processes [Vergesellschaftung] through which its interests are 
coalesced and its value orientations constructed. It is here that the possibility emerges of moving from the analysis of the middle class to an authentic sociology of the bourgeoisie as a social unit. The bourgeoisie is not a social layer that emanates naturally from the social structure, but a social form in constant mutation, which implies considering processes of bourgeoisification and debourgeoisification alike. The constitution of the bourgeoisie as a social unit involves external elements (the appropriation of economic resources) but also internal elements, such as the capacity to articulate common interests (at a political level) and attain self-recognition through particular forms of life orientation (at a cultural level).

At the broad historical level, Lepsius links the emergence of a bourgeois society to four fundamental processes: industrialization, democratization, professionalization and bureaucratization. While the first two enabled the emergence of the bourgeois class as a historical actor and expanded the horizons of the social structure itself, the latter two ran in the opposite direction and functioned as mechanisms for monopolization of resources and possibilities. Today he observes a weakening of the idea of bourgeois society - that is, the bourgeois social formation has lost its capacity to coalesce social interests. This process is accompanied by forces working towards a levelling and uniformization of social conditions. In this scenario, the bourgeois nature or the bourgeois way of being [Bürgerlichkeit] does not always correspond to predefined social groups: "the bourgeoisie is the association of middle classes, while bourgeois being is its typical mode of conducting life" (Lepsius, 2009: 167).

The main lesson I wish to take from Lepsius's research is that, despite the centrality of the concepts of 'class situation' and 'status group situation,' they should not be imagined to contain in any unilateral or polarized way the potentialities immanent to a Weberian theory of social classes. They need to be reunited on a common platform, a step that Lepsius achieves by using as a substrate the Weberian triad of ideas, interests and institutions. The theory of classes requires maintaining its link to social theory, undoubtedly, but how does the situation manifest today?

This question is directly addressed by Schwinn (2007 and 2014), who argues that two major paradigms currently compete for explanatory primacy on the issue of social inequalities: the class-based approach and the systems-based approach. In the class theory tradition, the inequality between individuals is conceived to derive from capitalism or the market, while in the systems theory paradigm (Luhmann, I985) the theme is limited to the differentiation of social orders. For the theory of classes, explanatory primacy falls to economic-social inequality and it is through this inequality that the social order becomes explicable. In the systems theory model, this causality is inverted and analytic priority is given to social differentiation. In this latter view, each specific social order involves the operation of distinct mechanisms 
of social inclusion and exclusion, which allows different forms and spaces of differentiation beyond the economic to be considered (including political, juridical, etc.). ${ }^{18}$ For Schwinn, however, both inequality and differentiation correspond to distinct criteria and shape distinct social structures, which is why it is not a question of advocating the primacy of either of these social realities. For him, the platform capable of reconciling these two questions is the tradition based on the Max Weber's theory of action: the latter allows the simultaneous and interconnected apprehension of the production and reproduction of inequalities, and of the differentiation of social orders. But in what way?

Contrary to systems theory, Schwinn emphasizes that we cannot ignore the constitutive effects of social inequalities on social structure. While in the systems-based approach, the criteria of inclusion/exclusion are internal and exclusive to each social sphere (power, money, prestige, competence, etc.), Weber's theory suggests that the 'resources' specific to one sphere can be converted to another: this is the case of money and power. On the other hand, contrary to theories of socioeconomic inequality, these notably focus their attention exclusively on the life potentialities of individuals, yet not all inequalities result from the possession of economic, political or symbolic resources alone. In this case the systems-based approach would be correct, which assumes that social institutions also determine (promote or restrict) an individual's possibilities for social insertion, as well as his or her lifestyle and life orientation. By moving beyond the unilateralism of those theoretical approaches focused on class, institutional approaches can help shed light on the diversity of the mechanisms responsible for generating inequality and, at the same time, show how social orders, in turn, also shape the phenomenon of social hierarchies.

However, while Weber allows us to preserve the autonomy of each analytic environment, we have yet to reach the level of integration - in other words, it remains to explain how they are related. It is at this level that the Weberian duality between ideas, interests (and institutions) is important. For Weber, interests are assumed and marked by determined ideas and, on the other hand, ideas also reflect and condition interests. In practice, this signifies that one represents a context of influence, but not of determination, for the other. Finally, it is important not to forget that these ideas must be understood through determined cultural components (or in Weber's terms, values) whose interpretative pattern is institutionalized in accordance with distinct rules and social resources. These cultural and social conditions need to be appropriated by social actors in order for a determined social order to be able to be produced and reproduced. Social differentiation emerges precisely from this dialectic relationship between social structures and social action. 


\section{FINAL CONSIDERATIONS: FOR THE CONTINUITY OF THE DEBATE}

The debate on social classes in Brazil has brought to light diverse epistemological and methodological conceptions. Extending way beyond the quantitative/qualitative dimension, this theme involves the relation between theory and empirical data to involve the intersection of conceptions concerning paradigmatic unity or diversity in the social sciences. This research terrain is both the space of dispute concerning the present conjuncture of Brazilian society, and also the different modes of doing sociology, understood as an instrument for rendering the social universe intelligible.

The historical-hermeneutic review of the parameters of Weber's theory of social inequality was a preliminary step that allowed us to foreground and reframe questions concerning the nature and, especially, the validity of this approach. The advanced state of the exegesis shows how Weberian thought on the phenomenon of inequality and stratification became modified over the course of his intellectual career. Differentiating the two versions (triadic and dual) of his theory of the social classes also enabled us to advance to the critical problematization of the mechanisms and processes involved in the reception and routinization of his theses in Brazil, in particular the premature fixation on some lineages perceived as the potential heirs of his original intuitions, relegating his role merely to the field of the history of ideas.

M. Rainer Lepsius, in one of his last public pronouncements, claimed that, given its singular capacity for connection [Anschlusfähigkeit], Weberian sociology gave rise to multiple developments and contributions, but has yet to be duly explored in terms of its core elements. Applying this reasoning to the theme of classes, we can also assert that Weber's work remains particularly underexploited in terms of the structural dimension (a field in which the Marxist approach to classes predominates) while the theme of status group tends to be 'culturalized,' generally reduced to the symbolic-expressive dimension of social segmentation. Weberian sociology constitutes a multidimensional platform that takes into account both economic-social and symbolic-cultural elements. Class and status group comprise typical-ideal analytic parameters, not a hiatus to be surpassed or even elements that overlap each other. Each of these spheres comprises a specific baseline of work via which diverse and independent research directions can be developed. However, at its basic core, the Weberian theme of stratification demands an approach capable of integrating elements of structural sociology (institutions), political sociology (interests) and cultural sociology (values). It does not generate a theory of society or of the social per se, but the latter is incomprehensible without the mechanism responsible for generating social hierarchy and group formation, just as the latter cannot be disconnected from the legality intrinsic to the social spheres or spheres of value that con- 
stitute the social configuration of the modern. These are precise contributions that, much more than pertaining to the historical level, conserve a permanent actuality and still await a productive application.

Received 07/30/20I5 | Approved oI/2I/20I6

Carlos Eduardo Sell has a PhD in Political Sociology and completed postdoctorate research at Ruprecht-Karls Universität Heidelberg. He is a professor at the Department of Sociology and Political Science at the Federal University of Santa Catarina (UFSC) and his main area of interest is sociological theory. He published the book Max Weber e a racionalização da vida (2013) which won the award for best scientific work in sociology from the National Association of Postgraduate Studies and Research in Social Sciences (ANPOCS) in 2014. 


\section{NOTES}

I Even so I entirely recommend this beautiful text to the reader and emphasize the value of its fundamental contribution: a reflection on the diverse ways of doing sociology in Brazil.

2 In the fourth edition, which became the standard edition of Economy and Society (1956), the second version (from I920) appears in the first part as Chapter IV (Status Groups and Classes). The older version was inserted in the second part of the book in the chapter "Political Communities," as item 6, under the title "The Distribution of Power within the Political Community: Class, Status, Party." Gerth and Mills in From Max Weber (1982) reproduced just the first version of the text and contributed decisively to the fact that this became the most widely accepted version of the Weberian theory of social stratification.

3 This is why in the re-edition of Weber's writings (Max Weber Gesamtausgabe) the fragment "Class, status, party" was placed alongside another six writings that demonstrate Weber's attempt to develop a typology of community forms [Gemeinschaften]: I) economic relations of communities in general; 2) domestic communities; 3) ethnic communities; 3) market communities; and 5) the prestige of power and national feeling, and finally "class, status, party."

4 Though this does not mean that the first version should be simply discarded. When read in retrospect and, in particular, taking into account the alterations and corrections made, it sheds light on important points of Weber's view of classes and social status groups.

5 Far from being a banal and secondary term, 'chance' possesses a special meaning in Weber's analyses and always indicates the contingent character of his observations. Class, in the economic sense of the term, thus indicates the life chances or opportunities that result from a person's insertion in the economic order.

6 According to Weber's list, these factors are: I) clear identification of immediate bearers of opposed interests; 2) a typically similar class situation (for the masses); 3) favourable technical-organizational conditions; and 4) the intellectual elaboration of common objectives. 
7 Incidentally, the translation of the German word 'Stand' by 'status' or 'status group' in the American literature, with all the theoretical consequences that derive from this fact, would merit a study by itself.

8 It is interesting to note how, in this context, type of education constitutes a fundamental factor. Education is an important element in terms of explaining status group forms of life and, on the other hand, type of education varies enormously as a function of the economic conditions and life chances. The commercial and property classes, for example, possess a special elective affinity with technical education, more so than with humanistic education. The connection between education and social stratification has been little explored by the Weberian interpreters of his sociology of education (Gonzales, 2000).

9 The capacity to appropriate economic goods in monopolistic form was utilized by Frank Parkin (1972) as a model for an interesting theory of social stratification.

Io The work concerned is A ética protestante e o espírito do capitalismo, translated by Irene and Tamás Szmrecsányi (Weber, 1967) from the English version by Talcott Parsons (The Protestant Ethic and the Spirit of Capitalism).

I I In passing we can note that the question of the character of social groups in Brazil's process of formation has received a prominent place in this literature, particularly in the case of Raymundo Faoro (1979), who argued that Brazil did not possess social classes. This theme was explored again in his exceptional study of the work of Machado de Assis (20II).

I2 In the excerpts of texts selected by the author, Max Weber appears just twice and only in sections discussing the concepts of caste and status group. Curiously the thinker was simply overlooked in the topic dedicated to social classes.

I3 Though I shall have to forego listing other examples, it is worth mentioning the equally classic text by Maria Silva de Carvalho Franco, Homens liures na ordem escravocrata, published in 1983 .

I4 To cite the author's own words: what I refer to when I speak of the non-Marxist tradition of class corresponds, to a certain extent, to what is routinely called today in 
the manuals the Weberian tradition. Undoubtedly this tradition, as I understand it, was constructed by a series of European authors from the end of the nineteenth century to the mid twentieth century, including Weber, Schumpeter, Giger, Halbwachs, Marshall, Renner, Corner, Lockwood and (Ralf) Dahrendorf. In fact I agree with Sorensen's observation that the primordial importance normally attributed to Weber in the literature on class analysis is somewhat curious, given his scarce and fragmented writings on the theme, although no less interesting for being so.

I5 Namely: I) High-level professionals, administrators and managers; 2) Low-level professionals, administrators and managers and high-level technicians; 3a) High-level non-manual routine employees; 3 b) Low-level non-manual routine employees; 4) Small proprietors and employers and self-employed workers; 5) Low-level technicians and supervisors of manual workers; 6) Skilled manual workers; 7a) Unskilled manual workers; 7b) Agricultural workers.

I6 This absolutely does not mean that promising works do not exist. Arenari and Torres Júnior (2006: 197-238), for example, setting out from the relation that Weber establishes between religion and social stratification, explore a line of analysis with an enormous potential for development.

I7 A market research institute founded in Heidelberg in 1979.

I8 In Brazil, Luhmann's theses concerning social inequality have been taken up from a 'critical' angle by, among others, Torres Júnior (20I4) and Bachur (2012).

\section{BIBLIOGRAPHY}

Arenari, Brand \& Torres Junior, Roberto Dutra. (2006). Intersubjetividade, socialização religiosa e aprendizado político: esboço de uma interpretação sociológica do pentecostalismo no Brasil. In: Souza, Jessé (ed.). A invisibilidade da desigualdade brasileira. Belo Horizonte: Ed. UFMG, p. 197-238.

Archer, Margaret. (2005). Realist social theory: The morphogenetic approach. Cambridge: Cambridge University Press, p. $33-64$. 
Bachur, João Paulo. (2012). Inclusão e exclusão na teoria de sistemas sociais: aspectos críticos. BIB - Revista Brasileira de Informacão Bibliográfica em Ciências Sociais, 73, p. 55-83.

Berger, Peter \& Vester, Michael. (1998). Alte Ungleichheiten, Neue Spaltungen. Leverkusen: Leske/Budrich.

Berger, Peter \& Hradil, Stefan. (I990). Lebenslagen, Lebensläufe, Lebensstile. Soziale Welt, 7. Göttingen: Schwartz.

Bourdieu, Pierre. (20II). Condição de classe e posição de classe. In: A economia das trocas simbólicas. São Paulo: Perspectiva, p. 3-26.

Bourdieu, Pierre. (2008). A distinção: crítica social do julgamento. São Paulo: Edusp.

Bourdieu, Pierre. (1987). What makes a social class? On the theoretical and practical existence of groups. Berkeley Journal of Sociology, 32, p. I-I7.

Cardoso, Fernando Henrique. (2003). Capitalismo e escravidão no Brasil Meridional. O negro na sociedade escravocrata do Rio Grande do Sul. 6th ed. Rio de Janeiro: Civilização Brasileira.

Cohn, Gabriel. (2003) [1979]. Crítica e resignação. Max Weber e a teoria social. São Paulo: Martins Fontes.

Faoro, Raymundo. (I979). Os donos do poder. Formação do patronato político brasileiro. 5th ed. Porto Alegre: Globo (vol. I). Faoro, Raymundo. (1974). Machado de Assis: a pirâmide e o trapézio. São Paulo: Companhia Editora Nacional.

Fernandes, Florestan. (1978) [I958]. O problema da indução na sociologia. In: Fundamentos empíricos da explicação sociológica. 3rd ed. São Paulo: Livros Técnicos e Científicos. Fernandes, Florestan. (1975). A revolução burguesa no Brasil. Ensaio de interpretação sociológica. Rio de Janeiro: Zahar.

Franco, Maria Sylvia de Carvalho. (1983). Homens liures na ordem escravocrata. 3rd ed. São Paulo: Kairós.

Freitas, Renan Springer de. (2010). A produção da pesquisa sociológica. In: Martins, Carlos Benedito \& Martins, Heloisa T. de Souza (eds.). Horizontes das ciências sociais no Brasil. São Paulo: ANPOCS/ Barcarolla/Instituto Ciência Hoje/Discurso Editorial, p. 53-78.

Goldthorpe, John H. (2004). The economic basis of social class. London: Centre for Analysis of Social Exclusion, London School of Economics. 
Goldthorpe, John H. (2002). Back to class and status: or why a sociologial view of social inequality should be re-asserted. Revista Española de investigaciones sociológicas, I37, pp. I-I6.

Goldthorpe, John H. (2000). On sociology: numbers, narratives, and the integration of research and theory. Oxford: Oxford University Press.

Goldthorpe, John H. (I996). Rational choice theory and large-scale data analysis. Oxford: Oxford University Press.

Goldthorpe, John H. (I992). Revised class schema. London: Social and Community Planning Research.

Goldthorpe, John H. (1992). The constant flux: a study of class mobility in industrial societies. Oxford: Clarendon Press.

Goldthorpe, John H. (I99I). The uses of history in sociology: reflections on some recent tendencies. Oxford: Nuffield College. Goldthorpe, John H. (1987). Social mobility and class structure in modern Britain. Oxford: Clarendon Press.

Goldthorpe, John H. (1963). The affluent worker: political attitudes and behaviour. Cambridge: Cambridge University Press.

Gonzalez, Wânia R. C. (2000). Educação e desencantamento do mundo: contribuições de Max Weber para a sociologia da educação. Doctoral Thesis. Faculdade de Educação/Universidade Federal do Rio de Janeiro.

Guerra, Alexandre et al. (eds). (2006). Atlas da nova estratificação social no Brasil. Vol. I: Classe média: desenvolvimento e crise. São Paulo: Cortez.

Hirano, Sedi. (2002). Castas, estamentos e classes sociais. Introdução ao pensamento sociológico de Marx e Weber. 3rd ed. Campinas: Unicamp.

Ianni, Octavio. (I97I). Teorias da estratificação social. Leituras sociológicas. 2nd ed. São Paulo: Cia. Editora Nacional.

Jackson, Luiz Carlos \& Blanco, Alejandro. (2014). Sociologia no espelho: ensaístas, cientistas sociais e críticos literários no Brasil e na Argentina (I930-I970). São Paulo: Ed. 34.

Konietzska, Dirk. (1994). Lebensstile im sozialstrukturellen Kontext. Ein theoretischer und empirischer Beitrag zur Analyse soziokultureller Ungleichheiten. Opladen: Westdeutscher Verlag $\mathrm{GmbH}$. 
Kreckel, Reinhard. (1992). Politische Soziologie der sozialen Ungleichheit. Frankfurt am Main: Suhrkamp.

Lepsius, M. Rainer. (2012). "Economia e sociedade": a herança de Max Weber à luz da edição de sua obra completa (MWG). Tempo social, 24/I, p. I37-I45.

Lepsius, M. Rainer. (2009). Interessen, Ideen und Institutionen. 2nd ed. Wiesbaden: VS Verlag.

Lepsius, M. Rainer. (I993). Parteiensystem und Sozialstruktur. Zum Problem der Demokratisierung der deutschen Gesellschaft. In: Demokratie in Deutschland. Göttingen: Vandenhoeck/Ruprecht, p. 25-50.

Lichtblau, Klaus. (20II). Die beiden Soziologien Max Webers. In: Die Eigenart der kultur- und sozialwissenschaftlichen Begriffsbildung. Wiesbaden: VS Verlag, p. 389-395.

Lockwood, David. (1958). The blackcoated worker: a study in class consciousness. London: Allen and Unwin.

Luhmann, Niklas. (1985). Zum Begriff der sozialen Klasse. In: Soziale Differenzierung. Zur Geschichte einer Idee. Opladen: Westdeutscher Verlag, p.II9-I62.

Mata, Sergio da. (2013). A fascinação weberiana. As origens da obra de Max Weber. Belo Horizonte: Fino Traço (vol. I).

Müller, Hans-Peter. (2002). Die drei Welten der sozialen Ungleichheit: Belohnungen, Prestige und Citizenship: ein Blick zurück auf Talcott Parsons und die funktionalistische Schichtungstheorie. Berliner Journal für Soziologie, I2/4, p. 485-503.

Müller, Hans-Peter. (I993). Sozialstruktur und Lebensstile. 2nd ed. Frankfurt: Suhrkamp.

Müller, Hans-Peter. (2008). Lebenschancen und Lebensstile. Die kulturellen Dimensionen sozialer Schichtung. In: Sigmund, Steffen et al. (eds.). Soziale Konstellation und historische Perspektive. Wiesbaden: VS Verlag, p. I77-206.

Parkin, Frank. (1972). Class inequality and political order. London: Paladin.

Neri, Marcelo. (2008). A nova classe média. Rio de Janeiro: Ed. FGV/IBRE/CPS.

Rössel, Jörg. (20II). Soziologische Theorien in der Lebenstillforschung. Kölner Zeitschrift für Soziologie und Sozialpädagogie, 5I, p. 35-6I. 
Santos, Figueiredo José Alcides. (2004). Questão de classe: teorias e debates acerca das classes sociais nos dias de hoje. Juiz de Fora, MG: Clio Edições Eletrônicas.

Scalon, Celi \& Santos, José Alcides Figueiredo. (2010). Desigualdades, classes e estratificação social. In: Martins, Carlos Benedito \& Martins, Heloisa T. de Souza (eds.). Horizontes das ciências sociais no Brasil. São Paulo: ANPOCS, p. 79-106.

Schluchter, Wolfgang. (20I4). O desencantamento do mundo: seis estudos sobre Max Weber. Rio de Janeiro: Ed. UFRJ.

Schwinn, Thomas. (2004). Differenzierung und soziale Ungleichheit. Die zwei Soziologie und ihre Verknüpfung. Frankfurt: Humanities Online.

Schwinn, Thomas. (2007). Soziale Ungleichheit. Bielefeld: Transcript.

Souza, Amaury de \& Lamounier, Bolivar. (2010). A classe média brasileira: ambições, valores e projetos de sociedade. São Paulo: Elsevier.

Souza, Jessé. (2013). Em defesa da sociologia: o economicismo e a invisibilidade das classes sociais. Revista Brasileira de Sociologia, I, p. I29-I58.

Souza, Jessé. (2012). Os batalhadores brasileiros. Nova classe média ou nova classe trabalhadora? Belo Horizonte: Ed. UFMG. Souza, Jessé. (2009). A ralé brasileira: quem é e como vive. Belo Horizonte: Ed. UFMG.

Souza, Jessé (2003). A construção social da sub-cidadania. Para uma sociologia política da modernidade periférica. Belo Horizonte: Ed. UFMG.

Souza, Jessé. (2000). A modernização seletiva: uma reinterpretação do dilema brasileiro. Brasília: Ed. UnB.

Torres Junior, Roberto Dutra. (20I4). O problema da desigualdade social na teoria da sociedade de Niklas Luhmann. Cadernos CRH, 27/72, p. 547-56I.

Vester, Michael et al. (200I). Soziale Milieus im gesellschaftlichen Strukturwandel. Zwischen integration und Ausgrenzung. Frankfurt: Suhrkamp.

Villas Bôas, Glaucia. (20I4). A recepção controversa de Max Weber no Brasil (I940-I980). DADOS - Revista de Ciências Sociais, 57/I, p. 5-33. 
Wacquant, Loïc. (2013). Poder simbólico e fabricação de grupos: como Bourdieu reformula a questão das classes. Novos estudos CEBRAP, 96, p. 87-103.

Weber, Max. (2009). Wirtschaft und Gesellschaft. Gemeinschaften. Edited by Wolfgang Mommsen and Michael Meyer. Tübingen: Mohr Siebeck (MWG I: 22-2).

Weber, Max. (I982). Classe, estamento e partido. Ensaios de Sociologia. 5th ed. Rio de Janeiro: Guanabara, p. 2 II-228. Weber, Max. (I980). Wirtschaft und Gesellschaft. Tübingen: Mohr Siebeck (WuG).

Weber, Max. (1967). A ética protestante e o espírito do capitalismo. Pioneira: São Paulo.

Weininger, Elliot B. (2005). Foundations of Pierre Bourdieu's class analysis. In: Wright, Erik Olin (ed.). Approaches to class analysis. Cambridge, UK: Cambridge University Press, p. 82-I I8. 


\section{MAX WEBER E O DEBATE SOBRE AS CLASSES}

SOCIAIS NO BRASIL

Resumo

É mister problematizar e reabrir o debate sobre a interpretação e a validade da teoria das classes sociais de Max Weber no Brasil. Contrariando sua redução à condição de precursora histórica, este estudo destaca as diferenças entre suas duas versões da teoria da estratificação em Economia e Sociedade e descreve o problemático processo de sua recepção no contexto acadêmico brasileiro. A partir da crítica à parcialidade dessas interpretações, apresenta-se a atual retomada dessa teoria no debate sociológico alemão com ênfase no trabalho de M. Rainer Lepsius, visando estimular a diversificação e aprofundamento da reflexão teórica sobre as classes sociais..

\section{MAX WEBER AND THE DEBATE ON SOCIAL CLASSES IN BRAZIL}

Abstract

This article argues for the need to reconsider and reframe the debate on the interpretation and validity of Max Weber's theory of social classes in Brazil. Countering its reduction to the condition of a historical precursor, the study highlights the differences between the two versions of his theory of stratification in Economy and Society and describes its problematic reception in the Brazilian academic context. Starting from a critique of the bias contained in these interpretations, the article presents its current revival in the German sociological debate with an emphasis on the work of $\mathrm{M}$. Rainer Lepsius aiming to stimulate a diversification and deepening of the theoretical reflection on social classes.
Palavras-chave

Max Weber;

Classes sociais;

Estratificação social;

M. Rainer Lepsius;

Economia e Sociedade.

\section{Keywords}

Max Weber;

Social classes;

Social stratification;

M. Rainer Lepsius;

Economy and Society. 